\title{
HGF/NK4 inhibited VEGF-induced angiogenesis in in vitro cultured endothelial cells and in vivo rabbit model
}

\author{
M. Nakabayashi ${ }^{2,3}$, R. Morishita ${ }^{1,2}$, H. Nakagami ${ }^{2}$, K. Kuba ${ }^{4}$, K. Matsumoto ${ }^{4}$, T. Nakamura ${ }^{4}$, \\ Y. Tano ${ }^{3}$, Y. Kaneda ${ }^{2}$ \\ ${ }^{1}$ Division of Gene Therapy Science, Osaka University Medical School, Suita, Japan \\ 2 Division of Gene Therapy Science, Graduate School of Medicine, Osaka University, Suita, Japan \\ ${ }^{3}$ Department of Ophthalmology, Graduate School of Medicine, Osaka University, Suita, Japan \\ ${ }^{4}$ Division of Biochemistry, Graduate School of Medicine, Osaka University, Suita, Japan
}

\section{Abstract}

Aims/hypothesis. As vascular endothelial growth factor (VEGF) plays a pivotal role in the development of diabetic retinopathy, inhibition of angiogenesis induced by VEGF is crucial to treat diabetic retinopathy. HGF (hepatocyte growth factor)/NK4, containing the $\mathrm{N}$-terminal hairpin domain and the four subsequent kringle domains of HGF, is considered as a specific antagonist for HGF. Our aim was to explore the inhibitory effects of $\mathrm{HGF} / \mathrm{NK} 4$ on angiogenesis induced by VEGF.

Methods. To analyze the in vivo angiogenesis, we used rabbit corneal micropocket assay. Proliferation and migration of human endothelial cells, expression of ets-1, an essential transcription factor for angiogenesis, and the phosphorylation of extracellular signalregulated kinase (ERK) was examined with or without HGF/NK4.

Results. Using corneal micropocket assay, in vivo administration of $\mathrm{HGF} / \mathrm{NK} 4$ inhibited angiogenesis induced by VEGF. HGF/NK4 inhibited proliferation and migration of human endothelial cells induced by VEGF in a dose-dependent manner. Interestingly, VEGF-mediated phosphorylation of ERK was significantly attenuated by HGF/NK4. Of importance, HGF/NK4 attenuated the increase in ets-1 protein stimulated by VEGF. Nevertheless, HGF/NK4 did not affect phosphorylation of VEGF receptor-2 [kinase domain region (KDR)/foetal liver kinase (Flk)-1]. Although tyrosine phosphatase inhibitor $\left(\mathrm{Na}_{3} \mathrm{VO}_{4}\right)$, or okadaic acid, serine-threonin kinase inhibitor, did not prevent the inhibition of ERK phosphorylation by HGF/NK4, co-incubation of HGF/NK4 with VEGF significantly diminished mitogen-activated protein (MAP) ERK kinase (MEK) phosphorylation $(p<0.01)$. Conclusions/interpretation. Overall, HGF/NK4 inhibited angiogenesis induced by VEGF through inhibition of phosphorylation of ERK and ets- 1 expression in in vitro cultured endothelial cells and in vivo rabbit model. [Diabetologia (2003) 46:115-123]

Keywords Vascular endothelial growth factor, retinopathy, angiogenesis, HGF, endothelial cell.
Received: 10 March 2002 / Revised: 1 July 2002 Published online: 6 December 2002

(C) Springer-Verlag 2002

Corresponding author: R. Morishita, Division of Gene Therapy Science, Osaka University Medical School, 2-2 Yamada-oka, Suita 565, Japan, E-mail: morishit@geriat.med.osaka-u.ac.jp Abbreviations: VEGF, Vascular endothelial growth factor; HGF, hepatocyte growth factor; KDR, kinase domain region; Flk, fetal liver kinase; MAPK, mitogen-activated protein kinase; ERK, extracellular signal-regulated kinase.
The morbidity and mortality associated with diabetes are largely attributable to the sequelae of microvascular and macrovascular disease. Over the past decade, dramatic progress has been achieved in elucidating the fundamental processes underlying the pathogenesis of these complications. Although renal and arterial diseases still remain the main causes of death in diabetic patients, ocular complications are major determinants of disability. Preretinal neovascularization and chronic retinal edema are two major sight-threatening complications that can occur during proliferative diabetic retinopathy. Angiogenic growth factors such as vascular endothelial growth factor (VEGF) are believed to play 
a pivotal role in the development of microvascular complications such as diabetic retinopathy [1]. Intraocular VEGF concentrations are increased in patients with active ocular neovascularization from proliferative diabetic retinopathy, central retinal vein occlusion, retinopathy of prematurity and rubeosis iridis $[2,3]$. As retinal ischaemia induces intraocular neovascularization, which often leads to glaucoma, vitreous haemorrhage and retinal detachment, presumably by stimulating the release of angiogenic molecules, VEGF plays a major role in mediating active intraocular neovascularization in patients with ischaemic retinal diseases such as diabetic retinopathy and retinal vein occlusion. Therefore, inhibition of angiogenesis induced by VEGF is considered to be crucial in the treatment of angiogenic diseases such as proliferative diabetic retinopathy.

This therapeutic strategy is supported by the observation that VEGF concentration in vitreous fluid declined after successful laser photocoagulation [2]. Although argon laser panretinal photocoagulation for proliferative diabetic retinopathy has been reported to reduce the incidence of blindness by $90 \%$ with relatively small amounts of treatment $[3,4]$, novel therapy for control of proliferative disease is required in patients with diabetes. Recently, a novel antagonist of HGF (hepatocyte growth factor) has been reported [5]. This molecule is composed of the N-terminal 447 amino acids of the HGFo-chain, containing the N-terminal hairpin loop and the first four kringle domains of the HGF protein, and this has been termed HGF/NK4. HGF/NK4 has no agonistic activity in terms of mitogenic, motogenic and morphogenic activity, and tyrosine phosphorylation of Met/HGF receptor [6]. HGF/NK4 binds to the Met/HGF receptor, but competitively inhibits the multiple biological activities of HGF. In this study, we show that a fragment of HGF (HGF/NK4) inhibits neovascularization induced by VEGF both in vivo and in vitro. HGF/NK4 could have the therapeutic potential to prevent retinal neovascularization, providing the opportunity to treat proliferative diabetic retinopathy.

\section{Materials and methods}

Rabbit corneal micropocket assay. Male New Zealand White rabbits (2 to $2.5 \mathrm{~kg}$ ) were used. Animals were anaesthetized with a mixture of xylazine $(5 \mathrm{mg} / \mathrm{kg})$ and ketamine $(50 \mathrm{mg} / \mathrm{kg})$. A corneal pocket was created with a cataract knife in the eye of the rabbit [7]. Into this pocket, an ethylene-vinyl-acetate copolymer slow-release pellet containing $200 \mathrm{ng}$ VEGF with or without $\mathrm{HGF} / \mathrm{NK} 4$ was implanted. The pellet was positioned $2 \mathrm{~mm}$ from the corneal limbus. The corneas of all the rabbits were observed daily and photographed by means of a digital camera from Nikon (Tokyo, Japan). To evaluate the inhibitory effect of HGF/NK4 on corneal neovascularization, the area of corneal neovascularization was measured by outlining an isosceles triangle with its apex at the centre of the pellet positioned $2 \mathrm{~mm}$ from the corneal limbus [8]. The area of the isosceles triangle served as a standardized area within which neovascularization was quantified. The area of neovascularization was then manually outlined and calculated using Macscope version 2.56S. The inhibitory effect of HGF/NK4 on neovascularization was expressed as the ratio within the standardized area. All experimental procedures were approved by the Osaka University Medical School Animal care and Use Committee and were in accordance with the 'Principles of laboratory animal care' (NIH publication no. 85-23, revised 1985).

Cell culture. Human aortic endothelial cells (passage 3) was obtained from Clonetics (San Diego, Calif., USA), and cultured in EBM medium supplemented with 5\% foetal calf serum in the standard fashion [9]. In addition, human retinal capillary endothelial cells (passage 3) was obtained from Cell System (San Diego, Calif., USA), and cultured in DMEM medium supplemented with $10 \%$ foetal calf serum in the standard fashion [9]. These cells showed the specific characteristics of endothelial cells by immunohistochemical examination and morphological observation. All the cells were used within passage 5 to 7 , while they showed specific characteristics of endothelial cells.

Assay for endothelial cell proliferation. Endothelial cells were plated sparsely at a density of $1 \times 10^{4}$ cells per well in collagen type I-coated 12-well dishes (Costar, Cambridge, Mass., USA), and then cultured for $24 \mathrm{~h}$ in EBM medium supplemented with $5 \%$ FBS. After the cells were cultured for a further $20 \mathrm{~h}$ in serum-free EBM medium, the medium was changed to fresh defined serum-free medium containing VEGF (3, 10 and $20 \mathrm{ng} / \mathrm{ml}$ ) or vehicle. To assess the inhibitory effect of $\mathrm{HGF} / \mathrm{NK} 4$ on cell proliferation, the cells were cultured in serum-free medium containing VEGF with or without HGF/NK4. Two days after stimulation with VEGF, an index of cell proliferation was assessed as cell count using a Coulter counter (Beckman Coulter, Fullerton, Calif., USA).

Inhibitory effect of $H G F / N K 4$ on migratory activity of $V E G F$. Sub-confluent endothelial cells were cultured for $20 \mathrm{~h}$ in serum-free EBM medium, and then cells were plated at a density of $1 \times 10^{4}$ cells per well in transwell chambers (Costar), equipped with a $8 \mathrm{~mm}$-diameter polycarbonate filter (pore size $5 \mu \mathrm{m})$, which were pre-coated with purified human fibronectin (Cappel, Aurora, Ohio, USA). Treatments consisted of the addition of $\operatorname{VEGF}(0,1,3,10,30 \mathrm{ng} / \mathrm{ml})$ with or without HGF/NK4 $(150,300,600 \mathrm{ng} / \mathrm{ml})$. After $5 \mathrm{~h}$ of culture, the noninvasive cells were removed with cotton swabs. The cells that had stuck to the under surface of the polycarbonate filter were fixed, stained with hematoxylin \& eosin, and finally counted with a microscope (5 fields/well).

Western blots. The effect of HGF/NK4 on tyrosine phosphorylation of the KDR/Flk-1 receptor was initially studied. Sub-confluent endothelial cells were cultured in serum-free EBM for $20 \mathrm{~h}$. Serum-starved cells were treated with VEGF $(20 \mathrm{ng} / \mathrm{ml})$ with or without $\mathrm{HGF} / \mathrm{NK} 4(20 \mu \mathrm{g} / \mathrm{ml})$ for $10 \mathrm{~min}$, washed with PBS containing $2 \mathrm{mmol} / \mathrm{l} \mathrm{Na}_{3} \mathrm{VO}_{4}$, and the cell lysate was centrifuged at $12000 \times g$ for $15 \mathrm{~min}$. The supernatant was treated with anti-phosphotyrosine antibody and protein G Sepharose. Alternatively, the supernatant was also treated with antiKDR/Flk-1 antibody and protein A Separose. Immunoprecipitated materials were washed with lysis buffer and solubilized with sample buffer for SDS/PAGE, electroblotted onto polyvinylidene difluoride membranes (Millipore, Bedford, Mass., USA), and probed with anti-KDR/Flk-1 antibody. The cells were extracted in lysis buffer composed of $20 \mathrm{mmol} / \mathrm{l} \mathrm{Tris} / \mathrm{HCl}(\mathrm{pH} 7.4)$, $10 \mathrm{mmol} / \mathrm{l}$ EDTA, $150 \mathrm{mmol} / \mathrm{l} \mathrm{NaCl}, 2 \mathrm{mmol} / \mathrm{l} \mathrm{Na} \mathrm{VO}_{4}, 5 \mu \mathrm{g} / \mathrm{ml}$ 


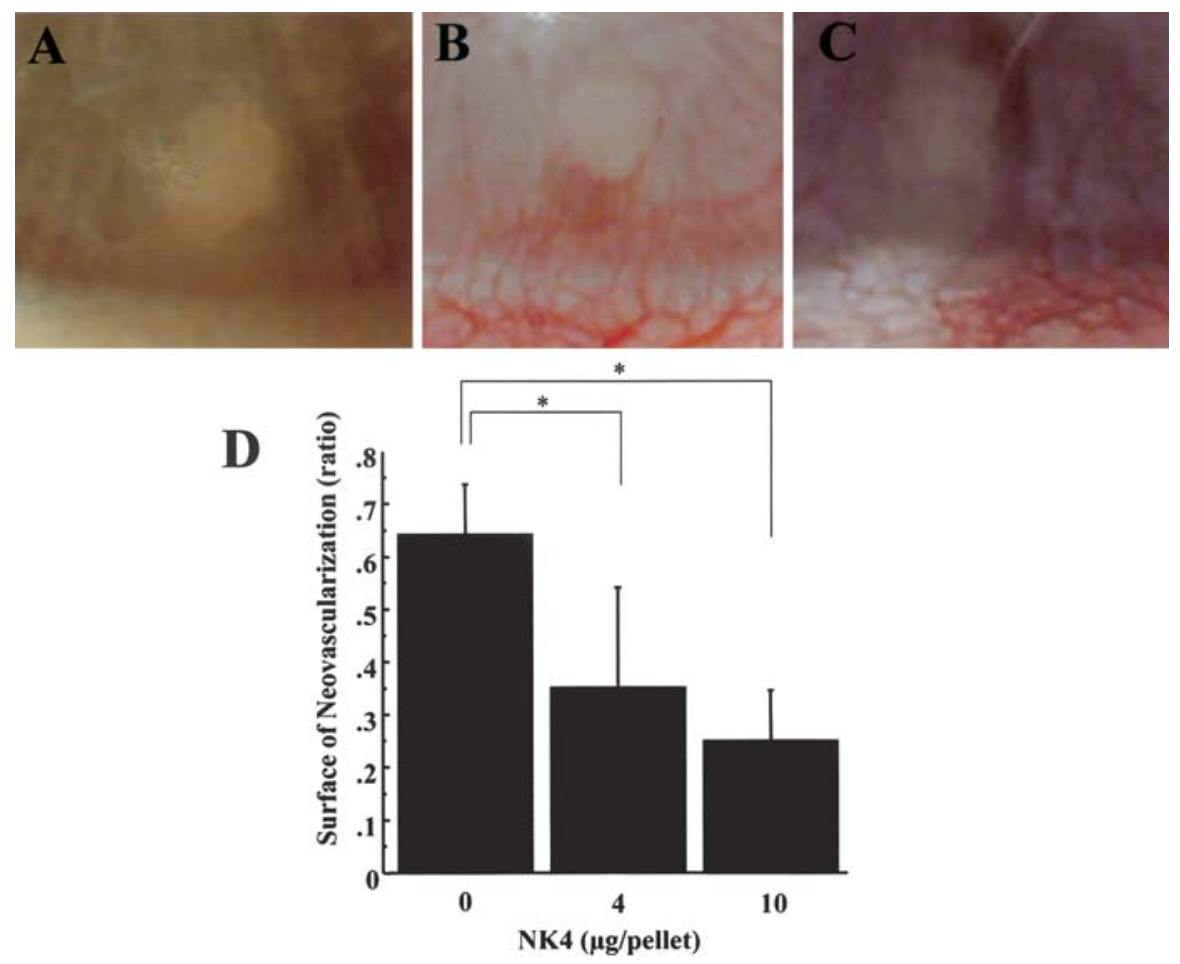

leupeptin, $1 \mathrm{mmol} / \mathrm{l}$ phenylmethylsulfonyl fluoride, and $0.5 \%$ Triton X-100, and extracted for $1 \mathrm{~h}$ at $4^{\circ} \mathrm{C}$. The proteins were separated by SDS-PAGE and electroblotted onto PVDF membranes and probed with antibodies. Proteins reacting with these antibodies were detected using an ECL enhanced chemiluminescence method (Amersham, Little Chalfont, UK).

The inhibitory effect of HGF/NK4 on ets-1 protein synthesis was also investigated. Experiments were carried out using 60-mm tissue culture dishes with a confluent cell monolayer. After $20 \mathrm{~h}$ of serum-starvation, cells were stimulated with VEGF $(5,10,20 \mathrm{ng} / \mathrm{ml})$ with or without HGF/NK4 (5, $20 \mu \mathrm{g} / \mathrm{ml}$ ) for $48 \mathrm{~h}$ and then extracted in lysis buffer. The proteins were separated by SDS-PAGE and electroblotted onto PVDF membranes and probed with anti-ets-1 antibody. Furthermore, we investigated the inhibitory effect of HGF/NK4 on p44/42 MAPK (ERK) or MEK phosphorylation. After $20 \mathrm{~h}$ of serum-starvation, cells were stimulated with $10 \mathrm{ng} / \mathrm{ml}$ VEGF and/or $\mathrm{HGF} / \mathrm{NK} 4(5,10 \mu \mathrm{g} / \mathrm{ml})$ for $10 \mathrm{~min}$, and cells were lysed in lysis buffer and extracted for $1 \mathrm{~h}$ at $4^{\circ} \mathrm{C}$. Proteins were separated by SDS-PAGE and electroblotted onto PVDF membranes and probed with anti-phospho-p44/42 MAPK or MEK antibody or anti-p44/42 MAPK or MEK antibody.

Materials. Phenylmethylsulfonyl fluoride, sodium orthovanadate $\left(\mathrm{Na}_{3} \mathrm{VO}_{4}\right)$, aprotinin, and other protease inhibitors were purchased from Sigma (St. Louis, Mo., USA). Recombinant human VEGF was obtained from R \& D (Minneapolis, Minn., USA). Polyclonal anti-phospho-p44/42 MAP kinase antibody was obtained from New England Biolabs (Beverly, Mass., USA). Polyclonal MEK antibody was obtained from New England Biolabs (Beverly, Mass., USA). Rabbit polyclonal antiEts-1 antibody (C-20), rabbit polyclonal anti-Flk-1 antibody (C-1158) and mouse monoclonal anti-phosphotyrosine antibody (PY99) were obtained from Santa Cruz Biotechnology (Santa Cruz, Calif., USA). Protein G and A Sepharose were obtained from Amersham Pharmacia Biotech (Uppsala, Sweden). Reagents for sodium dodecyl sulfate-polyacrylamide gel electrophoresis (SDS-PAGE) and immunoblotting were obtained from Bio-Rad (Richmond, Calif., USA).
Fig. 1A-D. (upper) Inhibition of VEGF-induced corneal neovascularization by $\mathrm{HGF} / \mathrm{NK} 4$ in rabbit corneal model at 7 days after stimulation. A Pellet containing vehicle. B Pellet containing $200 \mathrm{ng}$ VEGF. C Pellet containing $200 \mathrm{ng}$ VEGF and $10 \mu \mathrm{g}$ $\mathrm{HGF} / \mathrm{NK} 4$. D Inhibitory effect of HGF/NK4 on corneal neovascularization model at 7 days after pellet implantation. $n=7$ per group. $\mathrm{HGF} / \mathrm{NK} 4=$ rabbits treated with $\mathrm{HGF} / \mathrm{NK} 4(0,4$ and $10 \mu \mathrm{g}$ ) in pellets containing $200 \mathrm{ng}$ VEGF. ${ }^{*} p<0.01$ vs. $0 \mu \mathrm{g} / \mathrm{pellet} \mathrm{HGF} / \mathrm{NK} 4$

Statistical analysis. All values are expressed as means \pm SD. All experiments were repeated at least three times. Statistical analysis was done by analysis of variance, and the level of significance was a $p$ value of less than 0.05 .

\section{Results}

Inhibition of VEGF-induced angiogenesis by HGF/ NK4 in rabbit corneal neovascularization model. To examine whether HGF/NK4 can inhibit angiogenesis induced by VEGF, we implanted a sustained-release pellet containing $200 \mathrm{ng}$ VEGF with or without HGF/NK4 into a corneal pocket of New Zealand White rabbits $(n=21)$. New capillary vessels grew from the corneal limbus, across the cornea, and into the VEGF pellet within 6 days (Fig. 1B). In contrast, corneal neovascularization was inhibited in rabbits treated with a pellet containing 4 or $10 \mu \mathrm{g} \mathrm{HGF} / \mathrm{NK} 4$ (Fig. 1C). The area of neovascularization was smaller in rabbits treated with $10 \mu \mathrm{g} \mathrm{HGF} / \mathrm{NK} 4 \quad(p<0.01)$ (Fig. 1D). These results clearly showed that HGF/ NK4 has an anti-angiogenic effect on VEGFinduced angiogenesis in vivo. 

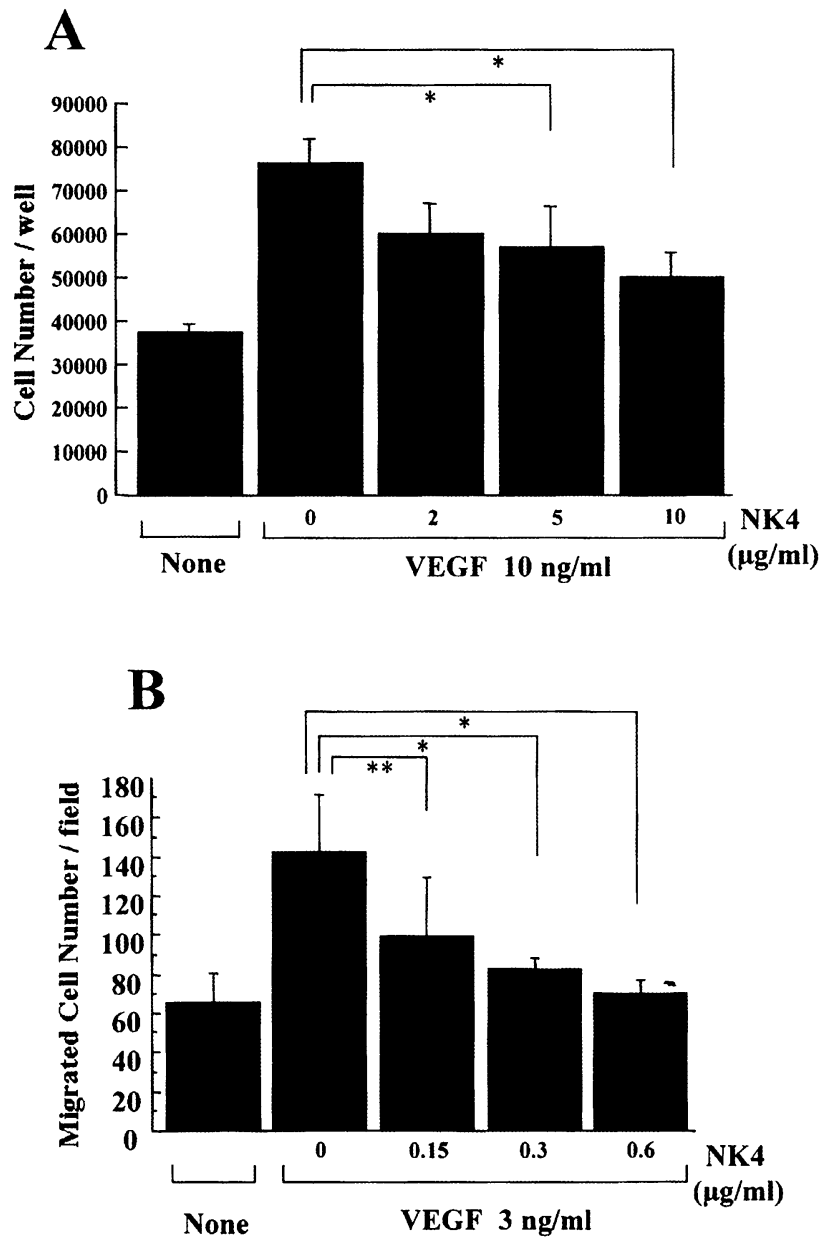

Fig. 2A, B. A Inhibitory effect of $\mathrm{HGF} / \mathrm{NK} 4$ on VEGF (10 $\mathrm{ng} / \mathrm{ml})$-induced cell proliferation at 2 days after treatment. None: VEGF $0 \mathrm{ng} / \mathrm{ml}$, NK4: 0, 2, 5, $10 \mu \mathrm{g} / \mathrm{ml}$. The data are representative of three independent experiments. $n=4$ per group. ${ }^{*} p<0.05$ vs. $0 \mu \mathrm{g} / \mathrm{ml} \mathrm{HGF} / \mathrm{NK} 4$. B Inhibition of VEGF ( $3 \mathrm{ng} / \mathrm{ml}$ )-induced cell migration by $\mathrm{HGF} / \mathrm{NK} 4$ at 4 days after treatment. None: VEGF $0 \mathrm{ng} / \mathrm{ml}, \mathrm{NK} 4: 0,0.15,0.3,0.6 \mu \mathrm{g} / \mathrm{ml}$. The data are representative of three independent experiments. $n=5$ per group. ${ }^{*} * p<0.01,{ }^{*} p<0.05$ vs $0 \mu \mathrm{g} / \mathrm{ml} \mathrm{HGF/NK} 4$

Inhibitory effect of HGF/NK4 on proliferation and migration of endothelial cells. Before establishing the effect of $\mathrm{HGF} / \mathrm{NK} 4$ on VEGF-induced endothelial cell proliferation, we investigated whether endothelial cells could respond to physiological levels of VEGF. We therefore tested the effect of VEGF on endothelial cell growth. Treatment of endothelial cells with VEGF resulted in an increase in the number of cells $(p<0.01)$ (Fig. 2A). No change in cell number was observed in the treatment with $3 \mathrm{ng} / \mathrm{ml}$ VEGF. Interestingly, addition of HGF/NK4 inhibited endothelial cell proliferation induced by VEGF in a dose-dependent manner $(p<0.05)$ (Fig. 2A). We further examined the effect of HGF/NK4 on mitogenic activity of endothelial cells induced by VEGF. Stimulation with VEGF induced migration of endothelial cells in a dose-dependent manner $(p<0.01)$ (data not shown). Importantly, addi- tion of HGF/NK4 dose-dependently inhibited the cell migration induced by VEGF $(p<0.01)$ (Fig. 2B).

Molecular mechanisms of inhibition of angiogenesis by HGF/NK4. Initially, we hypothesized that the inhibition of endothelial cell proliferation by HGF/NK4 is due to the inhibition of tyrosine autophosphorylation of VEGF receptor-2 [kinase domain region (KDR)/foetal liver kinase (Flk)-1] induced by VEGF. Tyrosine autophosphorylation of KDR/Flk-1 after addition of VEGF with or without HGF/NK4 was evaluated after immunoprecipitation and subsequent immunoblotting. Tyrosine autophosphorylation of KDR/ Flk-1 could be detected $10 \mathrm{~min}$ after the addition of VEGF, while simultaneous administration of $\mathrm{HGF} /$ NK4 and VEGF did not inhibit tyrosine autophosphorylation (Fig. 3A). No inhibition of tyrosine autophosphorylation by HGF/NK4 was also confirmed by immunoprecipitation with anti-KDR/Flk-1 antibody. These results showed that HGF/NK4 did not affect tyrosine autophosphorylation of the KDR/Flk-1 receptor induced by VEGF in endothelial cells.

Therefore, we further studied the effect of HGF/ NK4 downstream of the angiogenesis pathway. As the ets family takes part in regulating angiogenesis by controlling the transcription of these genes whose activity is necessary for the migration of endothelial cells from pre-existing capillaries, we examined the expression of ets-1 protein induced by VEGF. Western blot analysis showed that ets- 1 protein is up-regulated by VEGF in a dose-dependent way (Fig. 3B,C) $(p<0.05)$. Unexpectedly, co-incubation of $\mathrm{HGF} / \mathrm{NK} 4$ $(20 \mu \mathrm{g} / \mathrm{ml})$ with VEGF $(20 \mathrm{ng} / \mathrm{ml})$ for $48 \mathrm{~h}$ resulted in attenuation of ets-1 protein induced by VEGF $(P<0.01)$ (Fig. 4A,B). As previous reports documented a pivotal role of MAP kinases in ets- 1 activation by VEGF, we hypothesized that HGF/NK4 interferes with the MAP kinases, ERK, activation in human endothelial cells. As expected, after stimulation with VEGF, phosphorylation of ERK-1 and ERK-2 was observed from 5 min after stimulation using a specific antibody for the phosphorylated form of these kinases (Fig. 5A). Maximum induction of ERK phosphorylation was detected after $10 \mathrm{~min}$ of stimulation with VEGF (Fig. 5A). Importantly, co-incubation of HGF/ NK4 with VEGF diminished ERK phosphorylation $(p<0.01)$ (Fig. 5B,C). There was no change in nonphosphorylated ERK between cells treated with VEGF and HGF/NK4. To further elucidate the mechanisms, we examined the effects of $\mathrm{Na}_{3} \mathrm{VO}_{4}$, tyrosine phosphatase inhibitor, or okadaic acid, serine-threonin kinase inhibitor, on the inhibition of ERK phosphorylation by HGF/NK4. Unexpectedly, both inhibitors did not affect the inhibition of ERK phosphorylation by HGF/NK4 (data not shown). Thus, the inhibition of ERK phosphorylation by HGF/NK4 might not depend on phosphatase pathway. We then explored up-stream of the ERK pathway (Fig. 6), co-incubation of 


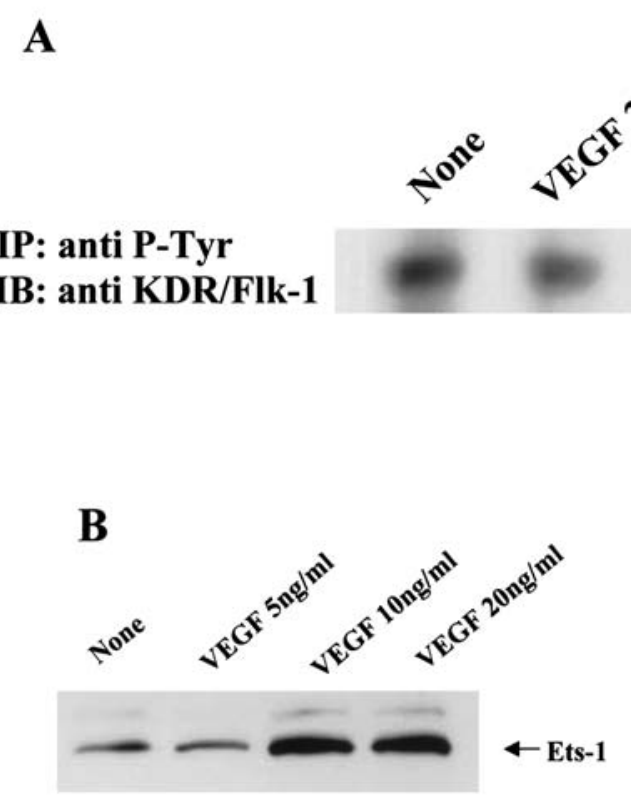

Fig. 3A-C. A Effects of VEGF with or without HGF/NK4 on tyrosine autophosphorylation of KDR/Flk-1 receptor. The KDR/Flk-1 receptor was immunoprecipitated with anti-phosphotyrosine (anti-P-Tyr) antibody and subjected to SDS/PAGE. Proteins were electroblotted onto a polyvinylidene difluoride membrane and probed with anti-KDR/Flk-1 antibody. $I P$, immunoprecipitation; $I B$, immunoblotting. None = untreated endothelial cells, VEGF $(20 \mathrm{ng} / \mathrm{ml})=\mathrm{VEGF}$ $(20 \mathrm{ng} / \mathrm{ml})$ alone, VEGF $(20 \mathrm{ng} / \mathrm{ml})+\mathrm{HGF} / \mathrm{NK} 4(20 \mu \mathrm{g} / \mathrm{ml})=$ VEGF (20 ng/ml) and HGF/NK4 $20 \mu \mathrm{g} / \mathrm{ml}, \mathrm{HGF} / \mathrm{NK} 4$

\section{$\mathbf{A}$}

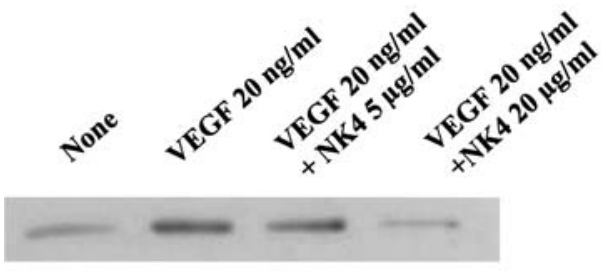

Fig. 4A, B. Inhibitory effect of HGF/NK4 on ets-1 protein expression induced by VEGF. A Western blot analysis for ets-1 protein at 2 days after treatment. None $=$ untreated endothelial cells, VEGF $20 \mathrm{ng} / \mathrm{ml}=\operatorname{VEGF}(20 \mathrm{ng} / \mathrm{ml})$, VEGF $20 \mathrm{ng} / \mathrm{ml}+$ $\mathrm{HGF} / \mathrm{NK} 45,20 \mu \mathrm{g} / \mathrm{ml}=\mathrm{VEGF}(20 \mathrm{ng} / \mathrm{ml})$ and $\mathrm{HGF} / \mathrm{NK} 4$ ( 5 or $20 \mu \mathrm{g} / \mathrm{ml}$ ). B Quantitative analysis of inhibitory effect of

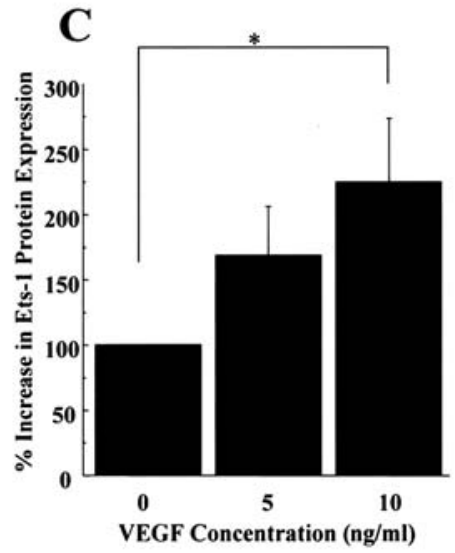

$(20 \mu \mathrm{g} / \mathrm{ml})=\mathrm{HGF} / \mathrm{NK} 4(20 \mu \mathrm{g} / \mathrm{ml})$ alone. B, C Effect of VEGF on ets- 1 protein expression. B Western blot analysis for ets- 1 protein at 2 days after treatment. None = untreated endothelial cells, VEGF 5, 10, $20 \mathrm{ng} / \mathrm{ml}=$ endothelial cells treated $\operatorname{VEGF}(5,10,20 \mathrm{ng} / \mathrm{ml})$. C Percentage increase in ets- 1 protein expression. VEGF $0=$ untreated endothelial cells, VEGF 5, $10 \mathrm{ng} / \mathrm{ml}=$ endothelial cells treated with $\operatorname{VEGF}(5,10 \mathrm{ng} / \mathrm{ml})$. These experiments were repeated three times. Values are expressed as percentage change in ets-1 protein induced by VEGF. ${ }^{*} p<0.05$ vs. VEGF 0

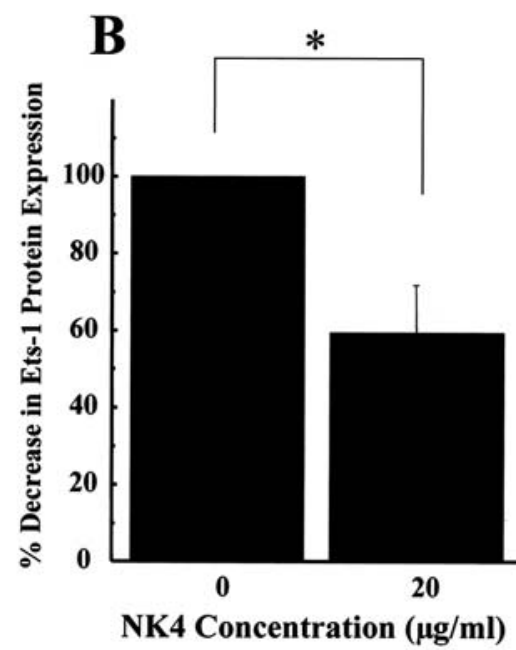

HGF/NK4 on ets-1 protein. HGF/NK4 $0=\operatorname{VEGF}(20 \mathrm{ng} / \mathrm{ml})$ without HGF/NK4, HGF/NK4 $20 \mu \mathrm{g} / \mathrm{ml}=$ VEGF $(20 \mathrm{ng} / \mathrm{ml})$ and HGF/NK4 $20 \mu \mathrm{g} / \mathrm{ml}$. These experiments were repeated three times. Values are expressed as percentage change in ets- 1 protein expression induced by VEGF. ${ }^{*} p<0.05$ vs. HGF/NK4 0 

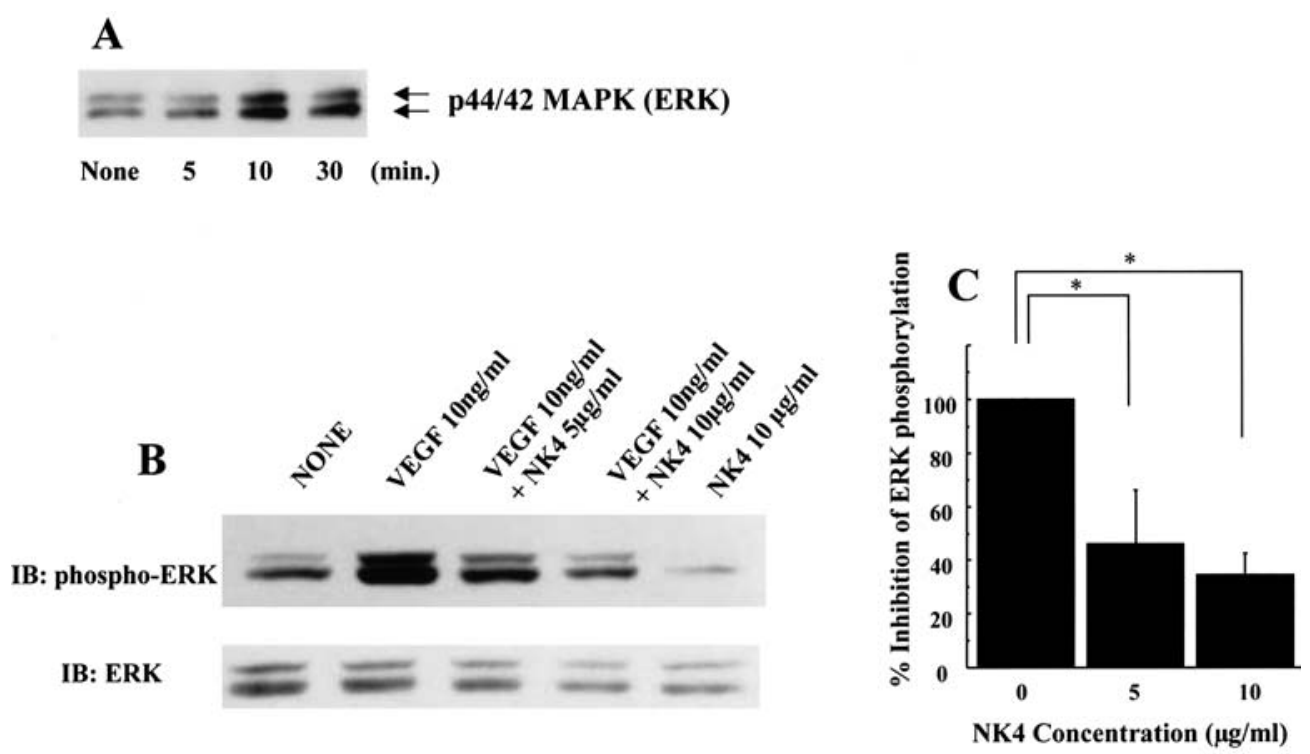

Fig. 5A-C. A Time course of ERK phosphorylation induced by VEGF. Cells were treated for 5,10 and $30 \mathrm{~min}$ with $10 \mathrm{ng} / \mathrm{ml}$ VEGF. None = untreated endothelial cells, 5, 10, $30 \mathrm{~min}=\mathrm{VEGF}(10 \mathrm{ng} / \mathrm{ml})$ at 5,10 and $30 \mathrm{~min}$ after treatment B Inhibitory effect of HGF/NK4 on ERK phosphorylation induced by VEGF at $10 \mathrm{~min}$ after stimulation. None = untreated endothelial cells, $10 \mathrm{ng} / \mathrm{ml}$ VEGF = VEGF $(10 \mathrm{ng} / \mathrm{ml})$, $10 \mathrm{ng} / \mathrm{ml} \mathrm{VEGF}+5,10 \mu \mathrm{g} / \mathrm{ml} \mathrm{HGF} / \mathrm{NK} 4=\mathrm{VEGF}(10 \mathrm{ng} / \mathrm{ml})$ and $\mathrm{HGF} / \mathrm{NK} 4$ (5 or $10 \mu \mathrm{g} / \mathrm{ml}), 10 \mu \mathrm{g} / \mathrm{ml} \mathrm{HGF} / \mathrm{NK} 4=$
$\mathrm{HGF} / \mathrm{NK} 4(10 \mu \mathrm{g} / \mathrm{ml})$ alone. IB immunoblotting. C Quantitative analysis for inhibitory effect of HGF/NK4 on ERK phosphorylation. HGF/NK4 $0=$ endothelial cells with VEGF (10 $\mathrm{ng} / \mathrm{ml})$ without HGF/NK4, HGF/NK4 5 or $10 \mu \mathrm{g} / \mathrm{ml}=$ endothelial cells treated with VEGF $(10 \mathrm{ng} / \mathrm{ml})$ and HGF/NK4 5 or $10 \mu \mathrm{g} / \mathrm{ml}$. These experiments were repeated three times. Values are expressed as percentage change in ERK phoshorylation induced by VEGF. * $p<0.01$ vs. $0 \mu \mathrm{g} / \mathrm{ml} \mathrm{HGF} / \mathrm{NK} 4$
$\mathbf{A}$

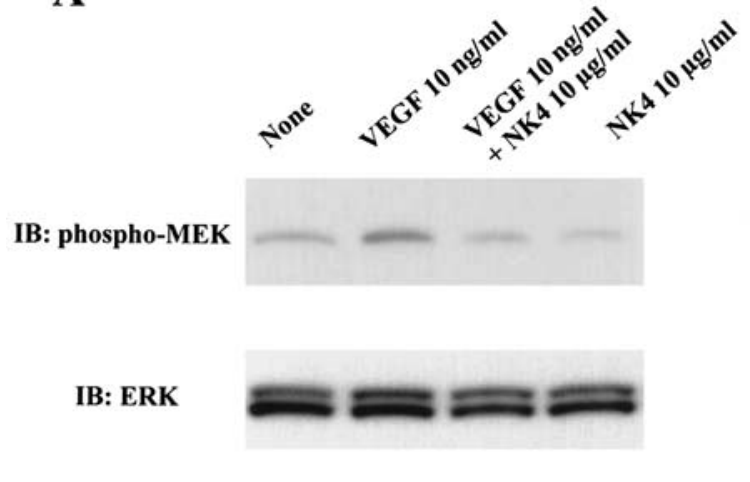

B

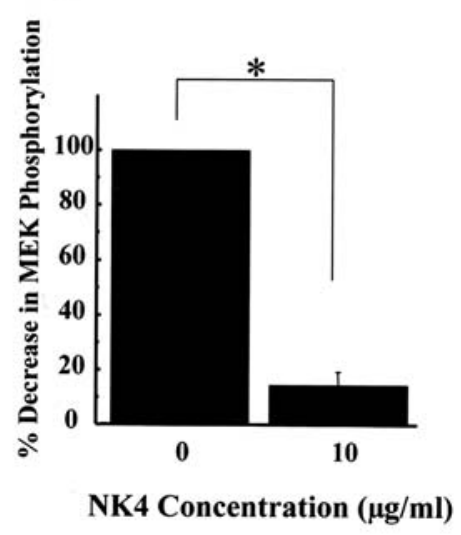

HGF/NK4 with VEGF diminished MEK phosphorylation $(p<0.01)$. Importantly, inhibition of ERK and MEK phosphorylation was also observed in human retinal capillary endothelial cells, similar to aortic endothelial cells (Fig. 7A-C).

\section{Discussion}

The formation of new blood vessels occurs as a result of the growth of capillaries by vascular sprouting from pre-existing vessels, a process called angiogenesis [14]. Angiogenesis is a complex phenomenon which includes at least four distinct properties of endothelial 
B
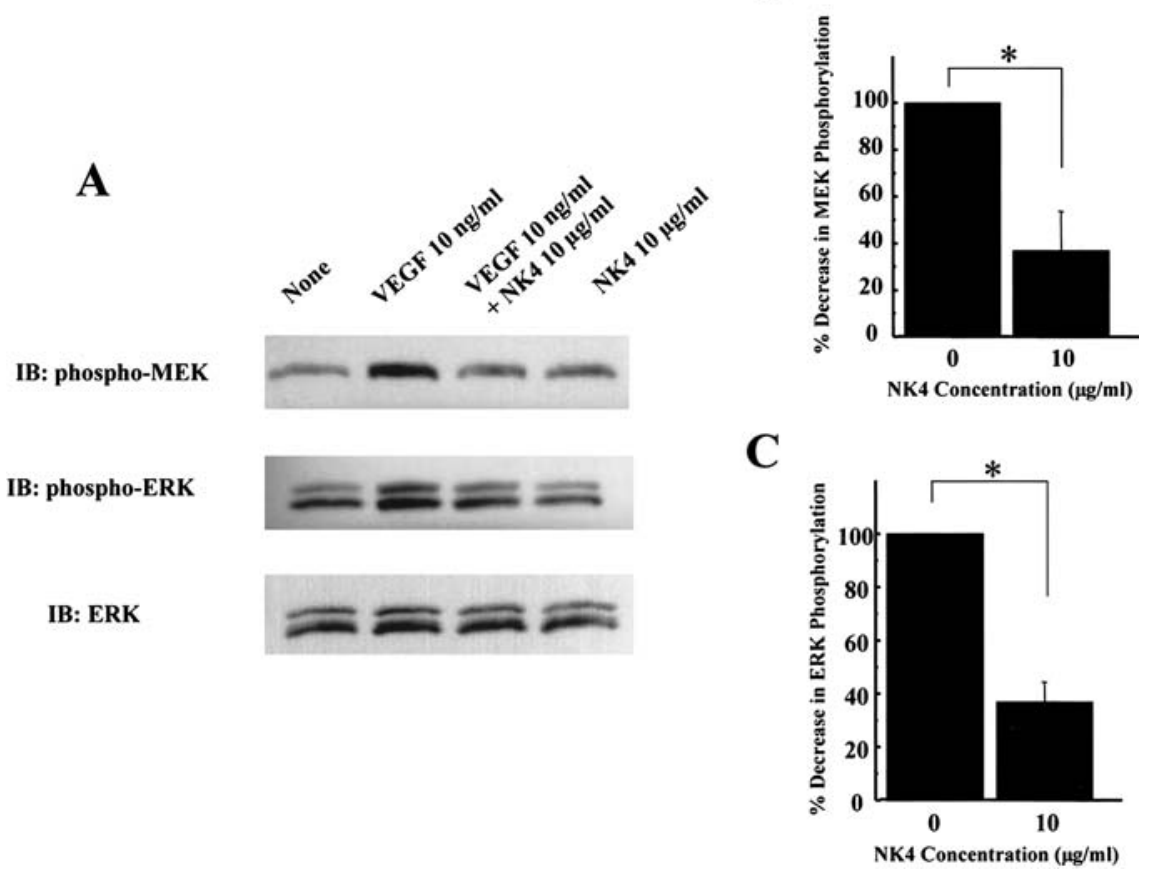

Fig. 7A-C. A Inhibitory effect of HGF/NK4 on ERK or MEK phosphorylation induced by VEGF at 10 min after stimulation in human retinal endothelial cells. None $=$ untreated endothelial cells, VEGF $10 \mathrm{ng} / \mathrm{ml}=$ VEGF $(10 \mathrm{ng} / \mathrm{ml})$, VEGF $10 \mathrm{ng} / \mathrm{ml}$ $+\mathrm{HGF} / \mathrm{NK} 410 \mu \mathrm{g} / \mathrm{ml}=\mathrm{VEGF}(10 \mathrm{ng} / \mathrm{ml})$ and $\mathrm{HGF} / \mathrm{NK} 4$ $(10 \mu \mathrm{g} / \mathrm{ml}), \mathrm{HGF} / \mathrm{NK} 410 \mu \mathrm{g} / \mathrm{ml}=\mathrm{HGF} / \mathrm{NK} 4(10 \mu \mathrm{g} / \mathrm{ml})$ alone. $I B$, immunoblotting. B, $\mathbf{C}$ Quantitative analysis for inhibitory effect of HGF/NK4 on ERK (B) and MEK (C) phosphorylation. HGF/NK4 $0=\operatorname{VEGF}(10 \mathrm{ng} / \mathrm{ml})$ without HGF/NK4, $\mathrm{HGF} / \mathrm{NK} 410 \mu \mathrm{g} / \mathrm{ml}=\mathrm{VEGF}(10 \mathrm{ng} / \mathrm{ml})$ and HGF/NK4 $10 \mu \mathrm{g} / \mathrm{ml}$. These experiments were repeated three times. Values are expressed as percentage change in MEK phoshorylation induced by VEGF. ${ }^{*} p<0.01$ vs. $0 \mu \mathrm{g} / \mathrm{ml} \mathrm{HGF/NK4}$

cells: degradation of vascular basement membrane and interstitial matrix by proteases such as plasminogen activators and matrix metalloproteinases, migration, proliferation, and tube formation. During these processes, various growth factors including fibroblast growth factor (FGF) family proteins, VEGF and epidermal growth factor family proteins are known to be stimulated. In contrast, recent studies have identified anti-angiogenic factors such as angiostatin and endostatin $[15,16]$. It is expected that these anti-angiogenic molecules could have therapeutic value against neovascular diseases such as cancer $[15,16,17]$. In addition to classical angiogenic disease, certain diseases such as proliferative diabetic retinopathy are considered to be angiogenic diseases. VEGF has been the centre of interest, since intraocular VEGF concentrations are increased in patients with active ocular neovascularization from proliferative diabetic retinopathy, central retinal vein occlusion, retinopathy of prematurity and rubeosis iridis [2, 3]. Moreover, VEGF also increases vascular permeability [18]. These character- istics of VEGF make it an important candidate to mediate the retinal vasoproliferative response to hypoxic stimuli observed in a variety of sight-threatening ischaemic retinal diseases [19]. Therefore, inhibition of angiogenesis by anti-angiogenic molecules might be beneficial to treat these ocular diseases.

Recently, a novel antagonist of HGF, HGF/NK4 containing the N-terminal 447 amino acids of the HGF $\alpha$-chain, the $\mathrm{N}$-terminal hairpin loop and the first four kringle domains of the HGF protein, have been reported [5]. HGF/NK4 has no agonistic activity in terms of mitogenic, motogenic and morphogenic activity, and tyrosine autophosphorylation of the Met/ HGF receptor [6]. HGF/NK4 binds to the Met/HGF receptor, but competitively inhibits the multiple biological activities of HGF. Although HGF/NK4 was originally identified as an antagonist for HGF, the findings that other kringle fragments such as angiostatin have a broad spectrum of anti-angiogenic activity induced by various growth factors gave the impression that $\mathrm{HGF} / \mathrm{NK} 4$ could also inhibit angiogenesis generally. Thus, we further examined whether HGF/NK4 has an inhibitory effect on VEGF-induced angiogenesis in vivo in this study. Surprisingly, we found that HGF/NK4 also had an inhibitory effect on angiogenesis induced by VEGF in a rabbit corneal neovascularization model. The inhibitory effect of HGF/NK4 on angiogenesis induced by VEGF is supported by facts: (i) HGF/NK4 inhibited angiogenesis induced by VEGF in a rabbit corneal neovascularization model; (ii) HGF/NK4 inhibited VEGF-induced endothelial cell proliferation and migration in a dosedependent manner using a culture model; (iii) activation of phosphorylation of ERK induced by VEGF was inhibited by HGF/NK4; (iv) the increase in an es- 
sential transcription factor, ets-1, for angiogenesis induced by VEGF was inhibited by HGF/NK4. Inhibition of phosphorylation of ERK by HGF/NK4 might explain its broad spectrum of anti-angiogenic activity, as activation of ERK in turn regulates a variety of cellular functions that are integral to angiogenesis, for example, stimulation of migration [20,21], suppression of adhesion [22], and stimulation of expression of matrix metalloproteinase-9 [23], urokinase [24, 25], and urokinase receptor [26]. Moreover, the MAP kinase kinase inhibitor, PD 098059, prevented tubule formation by sinusoidal endothelial cells without affecting their adhesion to the basement membrane matrix [27]. Inhibition of angiogenesis by HGF/NK4 might be mediated by interference with the activation of ERK-1 and ERK-2. The specificity of the inhibition of ERK phosphorylation by HGF/NK4 was confirmed by the previous report that HGF, but not VEGF, specifically activated c-Met in endothelial cells by increasing the phosphorylation on tyrosine residues, as shown by immunoprecipitation and Western blotting [34]. In addition, they also reported that HGF/NK4 alone, in concentrations up to $1000 \mathrm{nmol} / \mathrm{l}$, did not induce tyrosine phosphorylation of c-Met, and HGF/ NK4 also failed to activate c-Met in the presence of VEGF [34].

This study showed that HGF/NK4 inhibited up-regulation of ets-1 induced by VEGF. Members of the ets family play important roles in regulating gene expression in response to multiple developmental and mitogenic signals $[28,29,30]$. The ets family of transcription factors has a DNA-binding domain in common that binds to a core GGA(A/T) DNA sequence [31]. In situ hybridization studies have shown that the protooncogene c-ets is expressed in endothelial cells at the beginning of blood vessel formation, under normal and pathological conditions [10, 32]. It is believed that the ets family takes part in regulating angiogenesis by controlling the transcription of these genes whose activity is necessary for the migration of endothelial cells from pre-existing capillaries. Angiogenic factors such as aFGF, bFGF or VEGF have been reported to induce both ets-1 mRNA and protein [11]. In addition, we recently reported that HGF also induced ets- 1 activity and protein [33]. These results indicate that HGF/NK4 could inhibit expression of proteases via inhibition of ets-1 protein synthesis, resulting in the inhibition of angiogenesis. As HGF/NK4 did not affect tyrosine autophosphorylation of VEGF receptor-2 (KDR/Flk-1), HGF/NK4 might alter signal transduction at the receptor level. This study clearly showed that the inhibition of ERK phosphorylation by $\mathrm{HGF} / \mathrm{NK} 4$ is not due to phosphatase pathway, since both serine/threonine and tyrosine phosphatase inhibitors did not affect the inhibition of ERK phosphorylation. Interestingly, HGF/NK4 inhibited MEK phosphorylation at the up-stream of ERK. These results are not consistent with the previous report using human adult dermal microvascular endothelial cells and human lung-derived microvascular endothelial cells [34]. They reported that HGF/NK4 inhibited the proliferation of endothelial cells induced by VEGF, but this inhibition was not due to the blockade of ERK. It is not clear whether this difference is due to the origin of endothelial cells from microvascular or large vessels. Further studies are necessary to study the mechanisms of the inhibitory effects of HGF/NK4 on endothelial growth. The inhibitory effect of HGF/NK4 on angiogenesis induced by VEGF is supported by the in vivo rabbit corneal neovascularization model. Taken together, HGF/NK4 could inhibit angiogenesis through inhibition of phosphorylation of ERK and ets-1 protein synthesis downstream of tyrosine phosphorylation of KDR/Flk-1 at MEK level.

As previously reported, angiostatin, an endogenous inhibitor of angiogenesis, diminished activation of ERK in human dermal microvascular endothelial cells [35]. Both of these angiogenesis inhibitors (angiostatin and HGF/NK4) contain a similar protein structure, four kringle domains. Since appropriate folding of kringle structures is essential for angiostatin to maintain its full anti-endothelial activity [36], the kringle structures of HGF/NK4 may be essential to inhibit angiogenesis. We have shown that HGF/NK4, a novel HGF-antagonist, inhibits proliferation and migration of human endothelial cells, and phosphorylation of ERK and the increase in ets-1 protein synthesis induced by VEGF in in vitro cultured endothelial cells and in vivo rabbit model.

Acknowledgements. This work was partially supported by a grant from the Japan Health Sciences Foundation, a Grant-inAid from The Ministry of Public Health and Welfare, a Grantin-Aid for the Development of Innovative Technology, a Grant-in-Aid from Japan Promotion of Science, and Special Coordination Funds of the Ministry of Education, Culture, Sports, Science and Technology and the Japanese Government.

\section{References}

1. Cordeiro MF, Stanford MR, Phillips PM, Shilling JS (1997) Relationship of diabetic microvascular complications to outcome in panretinal photocoagulation treatment of proliferative diabetic retinopathy. Eye 11: 531-536

2. Aiello LP, Avery RL, Arrigg PG et al. (1994) Vascular endothelial growth factor in ocular fluid of patients with diabetic retinopathy and other retinal disorders. N Engl J Med 331: 1480-1487

3. Adamis AP, Miller JW, Bernal et al. (1994) Increased vascular endothelial growth factor levels in the vitreous fluid of eyes with proliferative diabetic retinopathy. Am J Ophthalmol 118: 445-450

4. Early Treatment Diabetic Retinopathy Study Research Group (1991) Early photocoagulation for diabetic retinopathy. ETDRS report no. 9. Ophthalmology 98: 766-785

5. Date K, Matsumoto K, Shimura H, Tanaka M, Nakamura T (1997) HGF/NK4 is a specific antagonist for pleiotrophic actions of hepatocyte growth factor. FEBS Lett 420: 1-6 
6. Date K, Matsumoto K, Kuba K, Shimura H, Tanaka M, Nakamura T (1998) Inhibition of tumor growth and invasion by a four-kringle antagonist (HGF/NK4) for hepatocyte growth factor. Oncogene 17: 3045-3054

7. Jain RK, Schlenger K, Hockel M, Yuan F (1997) Quantitative angiogenesis assays; Progress and problems. Nat Med 3: $1203-1208$

8. Amano S, Roban R, Kuroki M, Tolentino M, Adamis AP (1998) Requirement for vascular endothelial growth factor in wound- and inflammation-related corneal neovascularization. Invest Ophthalmol Vis Sci 39: 18-22

9. Morishita R,Nakamura S, Nakamura Y et al. (1997) Potential role of an endothelium-specific growth factor, hepatocyte growth factor, on endothelial damage in diabetes. Diabetes 46: 138-142

10. Wernert N Gilles F, Fafeur V, et al. (1994) Stromal expression of c-Ets 1 transcription factor correlates with tumor invasion. Cancer Res 54: 5683-5688

11. Sato Y (1998) Transcription factor ETS-1 as a molecular target for angiogenesis inhibition. Hum Cell 11: 207-214

12. Valter MM, Hugel A, Huang HJ et al. (1999) Expression of the Ets1 transcription factor in human astrocytomas is associated with Fms-like tyrosine kinase-1 (Flt-1)/vascular endothelial growth factor receptor-1 synthesis and neoangiogenesis. Cancer Res 59: 5608-5614

13. Kroll J, Waltenberger J (1997) The vascular endothelial growth factor KDR activates multiple signal transduction pathways in porcine aortic endothelial cells. J Biol Chem 272: 32521-32527

14. Folkman J, Shing Y (1992) Angiogenesis. J Biol Chem 267: 10931-10934

15. O'Reilly MS, Boehm T, Shing Y et al. (1994) Angiostatin: a novel angiogenesis inhibitor that mediates the suppression of metastases by a Lewis lung carcinoma. Cell 79: 315-328

16. O'Reilly MS et al. (1997) Endostatin: an endogenous inhibitor of angiogenesis and tumor growth. Cell 88: 277-285

17. O'Reilly MS, Holmgren L, Chen C, Folkman J (1994) Angiostatin induces and sustains dormancy of metastases by a Lewis lung carcinoma. Cell 79: 315-328

18. Dvorak HF, Brown LF, Detmer M, Dvorak AM (1995) Vascular permeability factor/vascular endothelial growth factor, microvascular hyperpermeability, and angiogenesis. Am J Pathol 146: 1029-1039

19. Klein R, Klein BEK (1985) Vision disorders in diabetes. In: Harris MI, Hamman RF (eds) Diabetes in America (NIH Publ. 85-1468). US Dept of Health and Human Services, Bethesda, MD, pp 1-2

20. Sa G, Murugesan G, Jaye M, Ivashchenko Y, Fox PL (1995) Activation of cytosolic phospholipase A2 by basic fibroblast growth factor via a p42 mitogen-activated protein kinase-dependent phosphorylation pathway in endothelial cells. J Biol Chem 270: 2360-2366

21. Klemke RL, Cai S, Giannini AL, Gallagher PJ, Lanerolle P de, Cheresh DA (1997) Regulation of cell motility by mitogen-activated protein kinase. J Biol Chem 137: 481492

22. Hughes PE, Renshaw MW, Pfaff M et al. (1997) Suppression of integrin activation: a novel function of a Ras/Rafinitiated MAP kinase pathway. Cell 88: 521-530
23. Gum R, Wang H, Lengyel E, Juarez J, Boyd D (1997) Regulation of $92 \mathrm{kDa}$ type IV collagenase expression by the jun aminoterminal kinase- and the extracellular signalregulated kinase-dependent signaling cascades. Oncogene 14: $1481-1493$

24. Besser D, Presta M, Nagamine Y (1995) Elucidation of a signaling pathway induced by FGF-2 leading to uPA gene expression in NIH3T3 fibroblasts. Cell Growth Differ 6: 1009-1017

25. Lengyel E, Stepp E, Gum R, Boyd D (1995) Involvement of a mitogen-activated protein kinase signaling pathway in the regulation of urokinase promoter activity by c-Ha-ras. J Biol Chem 270: 23007-23012

26. Lengyel E, Wang H, Gum R, Simon C, Wang Y, Boyd D (1997) Elevated urokinase-type plasminogen activator receptor expression in a colon cancer cell line is due to a constitutively activated extracellular signal-regulated kinase-1-dependent signaling cascade. Oncogene 14: 2563-2573

27. Maru Y, Yamaguchi S, Takahashi T, Ueno H, Shibuya M (1998) Virally activated ras cooperates with integrins to tubulogenesis in sinusoidal endothelial cell lines. J Cell Phys 176: 223-234

28. Vandenbunder B, Pardanaud L, Jaffredo T, Mirabel MA, Stehelin D (1989) Complementary patterns of expression of c-ets-1, c-myb and c-myc in the bloodforming systems of the chick embryo. Development 107: 265-274

29. Kola I, Brookes S, Green AR et al. (1993) The ets 1 transcription factor is widely expressed during murine embryo development and is associated with mesodermal cells involved in morphogenic processes such as organ formation. Proc Natl Acad Sci USA 90: 7588-7592

30. Queva C, Leprince D, Stehelin D, Vandenbunder B (1993) p54 $4^{\text {c-ets- } 1}$ and p68 ${ }^{\text {c-ets- } 1}$, the two transcription factors encoded by the c-ets- 1 locus, are differentially expressed during the development of chick embryo. Oncogene 8: 2511-2520

31. Wasylyk C, Gutman A, Nicholson R, Wasylik B (1991) c-ets oncoprotein activates the stromelysin promoter through the same elements as several non-nuclear oncoproteins. EMBO J 10: 1127-1134

32. Desbiens X, Queva C, Jaffredo T, Strehelin D, Vandenbunder B (1991) The relationship between cell proliferation and the transcription of the nuclear oncogenes c-myc, c-myb and c-ets- 1 during feather morphogenesis in the chick embryo. Development 111: 699-713

33. Aoki M, Morishita R, Taniyama Y et al. (2000) Angiogenesis induced by hepatocyte growth factor in non-infarcted myocardium and infarcted myocardium: up-regulation of essential transcription factor for angiogenesis, ets. Gene Ther 7: 417-427

34. Kuba K, Matsumoto K, Date K, Shimura H, Tanaka M, Nakamura T (2000) HGF/NK4, a four-kringle antagonist of hepatocyte growth factor, is an angiogenesis inhibitor that suppresses tumor growth and metastasis in mice. Cancer Res. 60: 6737-6743

35. Redlitz A, Daum G, Sage EH (1999) Angiostatin diminishes activation of the mitogen-activated protein kinases ERK-1 and ERK-2 in human dermal microvascular endothelial cells. J Vasc Res 36: 28-34

36. Cao Y, Ji RW, Davidson D et al. (1996) Kringle domains of human angiostatin. J Biol Chem 271: 29461-29467 